\title{
Determination of phosphorus in different types of waste using the ICP-MS technique
}

https://doi.org/10.21698/rjeec.2020.217

Proceedings Paper

\begin{abstract}
GINA ALINA CATRINA, LIDIA KIM*, AGNES SERBANESCU, GEORGIANA CERNICA, IONUT CRISTEA, MONA BARBU, ILEANA NICOLESCU, GABRIELA GEANINA VASILE
\end{abstract}

National Research and Development Institute for Industrial Ecology - ECOIND, 71-73 Drumul Podul Dambovitei, 060652, Bucharest, Romania

*Corresponding author (e-mail): lidia.kim@incdecoind.ro

\begin{abstract}
The research aimed to provide an optimal method for the determination of phosphorus concentration in different types of solid waste using inductive coupled plasma mass spectrometry (ICP-MS) technique. The analyzed waste matrices were: a) vegetable waste (P1), b) ash from the incineration of medical waste (P2), c) sewage sludge (P3) and d) sludge from the meat processing industry (P4). The experimental tests were performed to evaluate the detection limit, quantification limit, recovery, and expanded uncertainty for different types of waste using the ICP-MS method. The results indicate $0.1 \mathrm{mg} / \mathrm{kg}$ quantification limit, $2.3 \%$ intermediate precision, $13.1 \%$ expanded uncertainty, and $95.2 \%$ recovery for $P 4$ waste sample.

The results of the total phosphorus obtained by the ICP-MS method were compared to those from UV-VIS spectrometric method. The study concluded that the ICP-MS method leads to better results in a shorter time and with lower costs.
\end{abstract}

Keywords: total phosphorus, ICP-MS, solid waste, validation

\section{Introduction}

Phosphorus $(\mathrm{P})$ is an indispensable element for all life on Earth and, during the past decade, concerns about the future of its global supply have stimulated much research on waste which contains phosphorus in different forms $[1,2]$. Phosphorus occurs unnaturally in fertilizers (used in agriculture), cleaners (used in industry), and wastewater (from household sewage). Phosphorus is found in water, solids (detritus), and in the bodies of biological organisms. High levels of phosphorus in nature can create algal blooms causing eutrophication or the premature "aging" of a water body [3, 4]. Many chemical and biological processes need phosphorus from the environment, but too much phosphorus can create an imbalance in the ecosystem. Increasing the phosphorus content in fertilizers and laundry detergents may be due to human activities [5, 6]. Some forms of phosphorus are coming from human and animal wastes, food processing effluents, commercial fertilizers, industrial wastewater, agricultural land runoffs, and household detergents. The forms of phosphorus which are present in waste are orthophosphate, polyphosphate and organic phosphorus. Some chemical or biological reactions of phosphorus lead to the conversion of polyphosphates and organic phosphorus to orthophosphate by hydrolysis or microbial mobilization [6, 7]. Phosphorus from the environment must be monitored, as higher concentrations lead to environmental problems. It is a good indicator to estimate the growth of plants in agriculture, the multiplication of fish in different waters or the degree of decomposition of waste, etc. Phosphorus is one of the important elements to be detected in environmental, biological, geochemical, and metallurgical products $[6,7]$.

The colorimetric method (UV-VIS) for phosphorus determination is time-consuming and requires pretreatment of samples for the conversion of all the phosphates to the orthophosphate form for analysis. The major disadvantages of this method are that phosphorus concentration in some samples is too low to be detected by this method $[8,9]$. The inductively coupled plasma mass spectrometry (ICP-MS) method is characterized by a high detection efficiency and good reproducibility and is an accepted technique for quantitative analysis [10-12]. The basic setup for ICP-MS analysis requires the solid matrices an acid digestion procedure to transform the 
sample from solid form into a liquid form.

The purpose of the study was to establish an optimal method of determination for total

\section{MATERIALS AND METHODS}

\section{Equipment}

Microwave Digestion System Ethos Up Milestone, ICP-MS type 7900 Agilent with Mass Hunter 4.4 software, UV-VIS type 205

\section{Reagents and material}

The Certified Reference Material (CRM) 100 $\mathrm{mg} / \mathrm{L}$, the multielement standard contains 21 elements (metals and total phosphorous) was used for the calibration curve. The CRM multielement standard is traceable to NIST. The control of the results was performed with potassium dihydrogen phosphate $\left(\mathrm{KH}_{2} \mathrm{PO}_{4}\right.$, $1000 \mathrm{mg} / \mathrm{L}$ ) reagent.

The ascorbic acid, ammonium molybdate tetrahydrate, monopotassium phosphate, sulfuric acid, perchloric acid used for the UV-

\section{Methods applied}

To examine the optimal method, a Certified Reference Material Sewage Sludge 2 (CRM) was used to compare the obtained results with certified value.

To determine the total phosphorus content of the four samples, two digestion methods were used to decompose the organic matter (Fig. 1).

In the method I, the samples were digested in a microwave system (closed system): $0.50 \mathrm{~g}$ of sample was weighed and was added $0.5 \mathrm{~mL}$ $\mathrm{H}_{2} \mathrm{O}_{2}$ and $9.5 \mathrm{~mL} \mathrm{HNO}_{3}$. The samples were introduced into the digester for digestion at $140^{\circ} \mathrm{C}$ for $25 \mathrm{~min}$ and microwave power of $1250 \mathrm{~W}$.

In method II, the samples were digested in a refluxing installation: $0.5 \mathrm{~g}$ of sample with 2 $\mathrm{mL}$ of sulphuric acid and $5 \mathrm{~mL}$ of perchloric acid for $90 \mathrm{~min}$ at $400^{\circ} \mathrm{C}$. After the mineralization step, the samples were distilled, the color of the extracts was determined at 880 phosphorus from a different type of waste, to indicate additional data for the valorization process of this waste.
Specord Analytic Jena, Millipore Milli-Q Ultrapure Water System.

VIS spectrophotometric method were purchased from Merck. All the chemicals used in this research were of analytical reagent grade (Merck quality). Sewage sludge 2 (CRM) was purchased from Sigma Aldrich (lot LRAB4367, CRM029).

To accomplish the study were selected the following samples: a) vegetable waste (P1); b) ash from the incineration of medical waste (P2); c) sewage sludge (P3) and d) sludge from the meat processing industry $(\mathrm{P} 4)$.

nm wavelength.

Determination of total phosphorus was performed by inductively coupled plasma mass spectrometry (ICP-MS) in concentrations ranging from 100 to $500 \mu \mathrm{g} / \mathrm{L}$, respectively with the UV-VIS method in the range of 0.1 to 0.5 $\mathrm{mg} / \mathrm{L}$. The final result as the mean value of three determinations was reported in percentage.

The following performance parameters were evaluated in the experimental test: detection limit (LOD), quantitation limit (LOQ), repeatability $\left(\mathrm{RSD}_{\mathrm{r}}\right)$, intermediate precision $\left(\mathrm{RSD}_{\mathrm{Ri}}\right)$, recovery, and expanded uncertainty (Uex).

The experimental studies applied to perform inhouse validation of total phosphorus determination using the ICP-MS method are presented in Table 1.

Table 1. The in-house validation experiments

\begin{tabular}{l|l}
\hline \multicolumn{1}{c|}{ Parameters } & \multicolumn{1}{c}{ Experiments } \\
\hline LOD and LOQ & 10 independent fortified sample solutions of $25 \mu \mathrm{g} / \mathrm{L}$ \\
Repeatability & 10 independent fortified sample solutions of $150 \mu \mathrm{g} / \mathrm{L}$ \\
Intermediate precision & 12 independent fortified sample solutions of $150 \mu \mathrm{g} / \mathrm{L}$ \\
Recovery & 5 independent fortified sample solutions with $250 \mu \mathrm{g} / \mathrm{L}$ \\
\hline
\end{tabular}




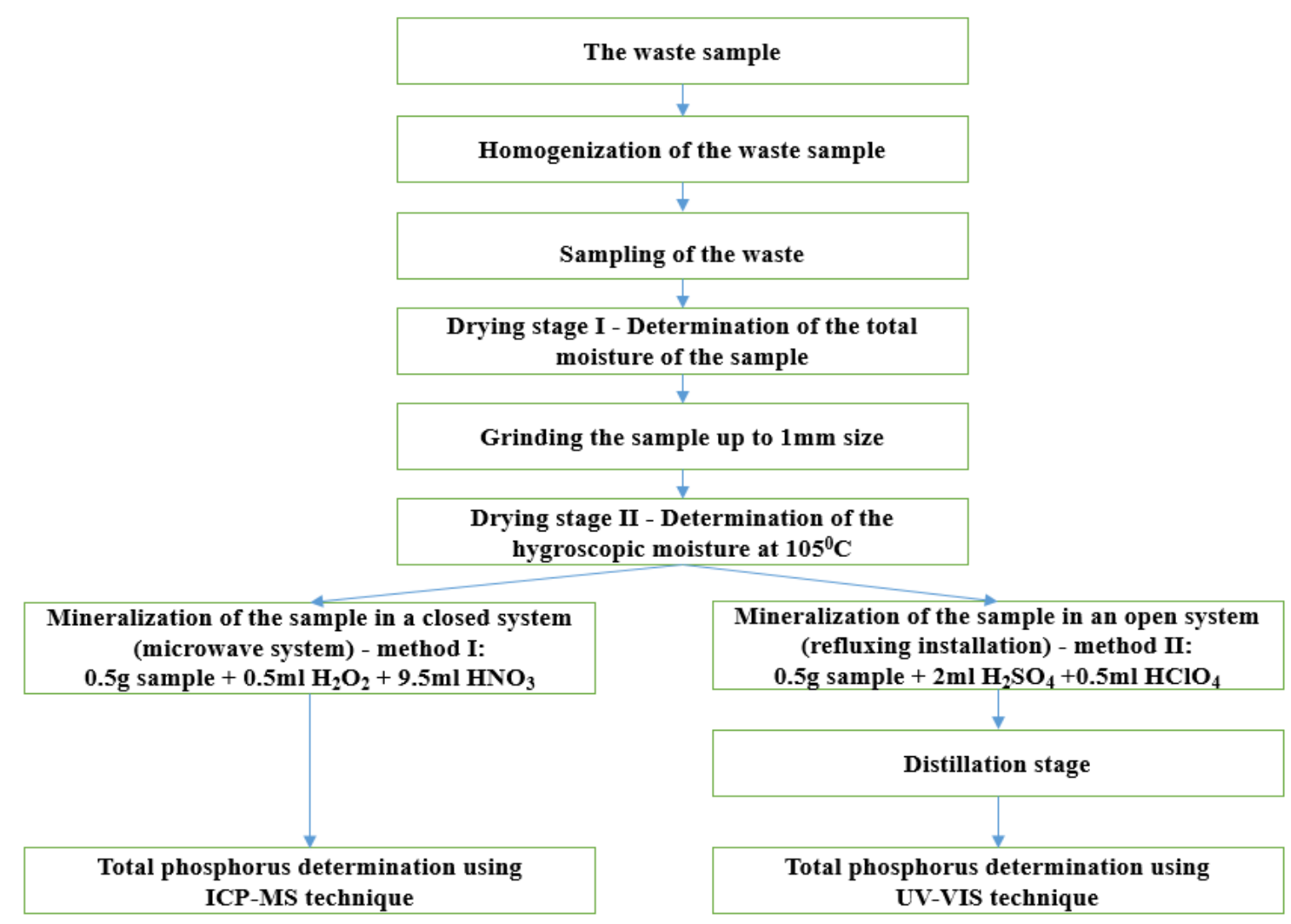

Fig. 1. The preparation and characterization of the waste sample

\section{Interference studies}

The interferences that could influence the results for total phosphorus determination include metal cations such as $\mathrm{Fe}, \mathrm{Cr}, \mathrm{Cd}, \mathrm{Pb}$, and $\mathrm{Zn}$. In the experimental studies, for each metal, three concentrations were tested for the

\section{RESULTS AND DISCUSSIONS}

\section{In-house validation experiments}

The validation was performed on real samples as follows: P1, vegetable waste; P2, ash from the incineration of medical waste; $\mathrm{P}$ 3, sewage sludge and $\mathrm{P} 4$, sludge from the meat processing industry.

In Table 2 are presented the values of performance parameters obtained in the in-house validation experiments using the ICP-MS technique for all the analyzed matrices. The same total phosphorus concentration and the recovery yield for total phosphorus was calculated. The concentrations for the studied interferences were $150 \mu \mathrm{g} / \mathrm{L}, 350 \mu \mathrm{g} / \mathrm{L}$ and 450 $\mu \mathrm{g} / \mathrm{L}$. calibration plot was performed in the range of 100 to $500 \mu \mathrm{g} / \mathrm{L}$ (ICP-MS method). In complex matrices, the determination of the detection limit should be performed in a solution containing relevant interference substances [13].

No important differences were reported, small differences between results are due to the chemical composition and source of the waste (Table 2).

Table 2. Performance parameters for total phosphorus using ICP-MS technique

\begin{tabular}{c|cccccc}
\hline Sample & $\begin{array}{c}\text { LOD } \\
(\mathrm{mg} / \mathrm{kg})\end{array}$ & $\begin{array}{c}\mathrm{LOQ} \\
(\mathrm{mg} / \mathrm{kg})\end{array}$ & $\begin{array}{c}\mathrm{RSD}_{\mathrm{r}}{ }^{*} \\
(\%)\end{array}$ & $\begin{array}{c}\mathrm{RSD}_{\mathrm{Ri}} * * \\
(\%)\end{array}$ & $\begin{array}{c}\text { Uex } \\
(\%)\end{array}$ & $\begin{array}{c}\text { Recovery } \\
(\%)\end{array}$ \\
\hline P1 & 0.028 & 0.11 & 0.81 & 1.95 & 12.2 & 97.6 \\
P2 & 0.033 & 0.13 & 0.95 & 2.10 & 13.6 & 96.8 \\
P3 & 0.021 & 0.08 & 0.96 & 1.43 & 11.5 & 98.9 \\
P4 & 0.026 & 0.10 & 1.16 & 2.33 & 13.1 & 95.2 \\
\hline \multicolumn{7}{r}{ *Repeatability test; **Intermediate precision; ***Measurement uncertainty }
\end{tabular}


The selectivity of the proposed method

The presence of other elements may constitute interference in the reporting of true results. Five interfering elements were chosen based on the composition of each analyzed waste. In experimental tests were studied the potential interferences in total phosphorus determination of iron, chromium, cadmium, lead, and zinc cations.

For the interference's studies were prepared aqueous synthetic solutions that contain known concentrations of metals and total phosphorus. Five interfering elements were chosen based on the composition of each analyzed waste. The studied concentrations of $\mathrm{Fe}, \mathrm{Cr}, \mathrm{Cd}, \mathrm{Pb}$, and $\mathrm{Zn}$ in all waste samples (P1 to P4) were $150 \mu \mathrm{g} / \mathrm{L}$, $350 \mu \mathrm{g} / \mathrm{L}, 450 \mu \mathrm{g} / \mathrm{L}$. The cations interferences were tested and the results are presented in Table 3.

Table 3. The recovery percentage for total phosphorous in interference tests

\begin{tabular}{|c|c|c|c|}
\hline \multirow[b]{2}{*}{ Iron $(\mu \mathrm{g} / \mathrm{L})$} & \multicolumn{2}{|c|}{ Total phosphorus concentration $(\mu \mathrm{g} / \mathrm{L})$} & \multirow[b]{2}{*}{$\begin{array}{c}\text { Recovery yield } \\
(\%)\end{array}$} \\
\hline & $\begin{array}{l}\text { Added } \\
(\mu \mathrm{g} / \mathrm{L})\end{array}$ & $\begin{array}{l}\text { Recovered } \\
(\mu \mathrm{g} / \mathrm{L})\end{array}$ & \\
\hline 0 & 250 & 247 & 98.8 \\
\hline 150 & 250 & 242 & 96.8 \\
\hline 350 & 250 & 237 & 94.8 \\
\hline 450 & 250 & 233 & 93.2 \\
\hline \multirow[b]{2}{*}{ Chromium $(\mu \mathrm{g} / \mathrm{L})$} & \multicolumn{2}{|c|}{ Total phosphorus concentration $(\mu \mathrm{g} / \mathrm{L})$} & \multirow{2}{*}{$\begin{array}{l}\text { Recovery yield } \\
(\%)\end{array}$} \\
\hline & $\begin{array}{l}\text { Added } \\
(\mu \mathrm{g} / \mathrm{L})\end{array}$ & $\begin{array}{l}\text { Recovered } \\
(\mu \mathrm{g} / \mathrm{L})\end{array}$ & \\
\hline 0 & 250 & 244 & 97.6 \\
\hline 150 & 250 & 240 & 96.0 \\
\hline 350 & 250 & 235 & 94.0 \\
\hline 450 & 250 & 229 & 91.6 \\
\hline \multirow[b]{2}{*}{ Cadmium $(\mu \mathrm{g} / \mathrm{L})$} & \multicolumn{2}{|c|}{ Total phosphorus concentration $(\mu \mathrm{g} / \mathrm{L})$} & \multirow{2}{*}{$\begin{array}{c}\text { Recovery yield } \\
(\%)\end{array}$} \\
\hline & $\begin{array}{l}\text { Added } \\
(\mu \mathrm{g} / \mathrm{L})\end{array}$ & $\begin{array}{l}\text { Recovered } \\
(\mu \mathrm{g} / \mathrm{L})\end{array}$ & \\
\hline 0 & 250 & 246 & 98.4 \\
\hline 150 & 250 & 240 & 96.0 \\
\hline 350 & 250 & 237 & 94.8 \\
\hline 450 & 250 & 230 & 92.0 \\
\hline \multirow[b]{2}{*}{ Lead $(\mu \mathrm{g} / \mathrm{L})$} & \multicolumn{2}{|c|}{ Total phosphorus concentration $(\mu \mathrm{g} / \mathrm{L})$} & \multirow[b]{2}{*}{$\begin{array}{c}\text { Recovery yield } \\
(\%)\end{array}$} \\
\hline & $\begin{array}{l}\text { Added } \\
(\mu \mathrm{g} / \mathrm{L})\end{array}$ & $\begin{array}{l}\text { Recovered } \\
(\mu \mathrm{g} / \mathrm{L})\end{array}$ & \\
\hline 0 & 250 & 245 & 98.0 \\
\hline 150 & 250 & 241 & 96.4 \\
\hline 350 & 250 & 233 & 93.2 \\
\hline 450 & 250 & 228 & 91.2 \\
\hline \multirow[b]{2}{*}{$\operatorname{Zinc}(\mu \mathrm{g} / \mathrm{L})$} & \multicolumn{2}{|c|}{ Total phosphorus concentration $(\mu \mathrm{g} / \mathrm{L})$} & \multirow{2}{*}{$\begin{array}{c}\text { Recovery yield } \\
(\%)\end{array}$} \\
\hline & $\begin{array}{l}\text { Added } \\
(\mu \mathrm{g} / \mathrm{L})\end{array}$ & $\begin{array}{l}\text { Recovered } \\
(\mu \mathrm{g} / \mathrm{L})\end{array}$ & \\
\hline 0 & 250 & 249 & 99.6 \\
\hline 150 & 250 & 248 & 99.2 \\
\hline 350 & 250 & 246 & 98.4 \\
\hline 450 & 250 & 240 & 96.0 \\
\hline
\end{tabular}

Based on the tested concentration level, the recovery percentage should be situated in the range of 75 to $125 \%$ [13]. All obtained results for recovery yields fall within the accepted range.
The addition of cations in the concentration range $150 \mu \mathrm{g} / \mathrm{L}$ to $450 \mu \mathrm{g} / \mathrm{L}$ does not influence the determination of total phosphorus using the ICP-MS technique. All recovery yield values were above $91 \%$ regardless of the cation or 
concentration used.

Another category of interfering substances could be anions (sulfates, chlorides, nitrates, phosphates, fluorides), which will be studied in the future.

Determination of the total phosphorus using the ICP-MS technique

The phosphorus content decrease in all studied wastes in the following order: $\mathrm{P} 4>\mathrm{P} 3>\mathrm{P} 1>\mathrm{P} 2$ (Fig. 2). It was observed that the $\mathrm{P} 4$ sample (sludge from the meat processing industry) shows higher content of total phosphorus compared to the other three samples of waste for both digestion methods applied. Sample P4 contains food additives expressed as $\mathrm{P}_{2} \mathrm{O}_{5}$ that are added to meat and other food products, as a result of their role in fats and proteins emulsification and stimulation of water binding.

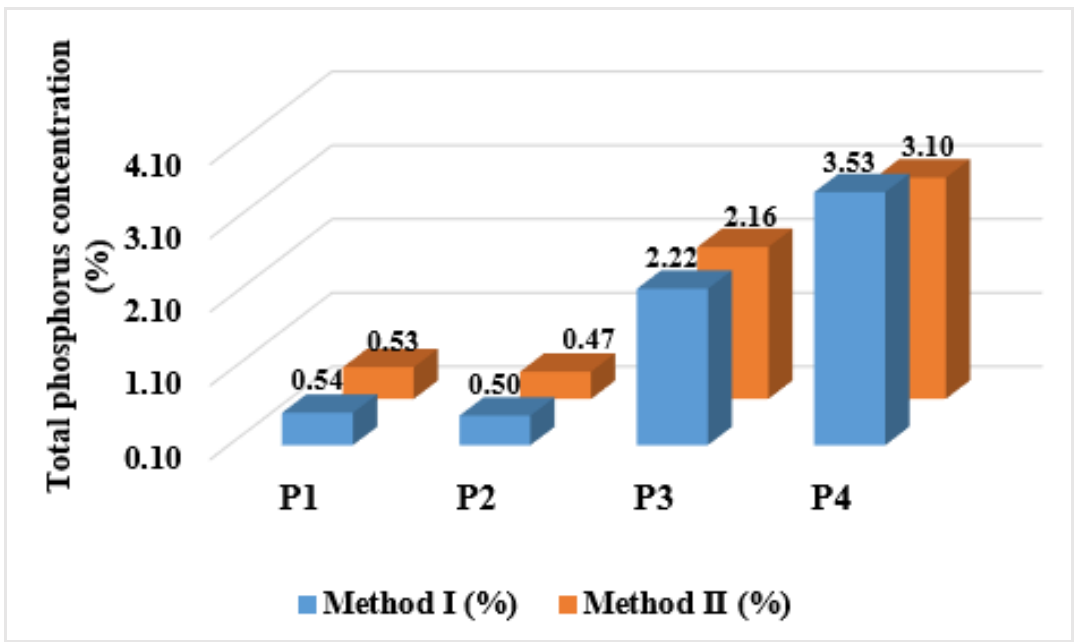

Fig. 2. Graphic representation of total phosphorus concentration obtained with the ICP-MS technique

Determination of the total phosphorus using the UV-VIS technique

Same P4 waste sample has higher total order between samples were reported, phosphorus results, when the UV-VIS method comparable results with a previous study (ICPwas applied (Fig. 3). No differences in content MS method) were obtained.

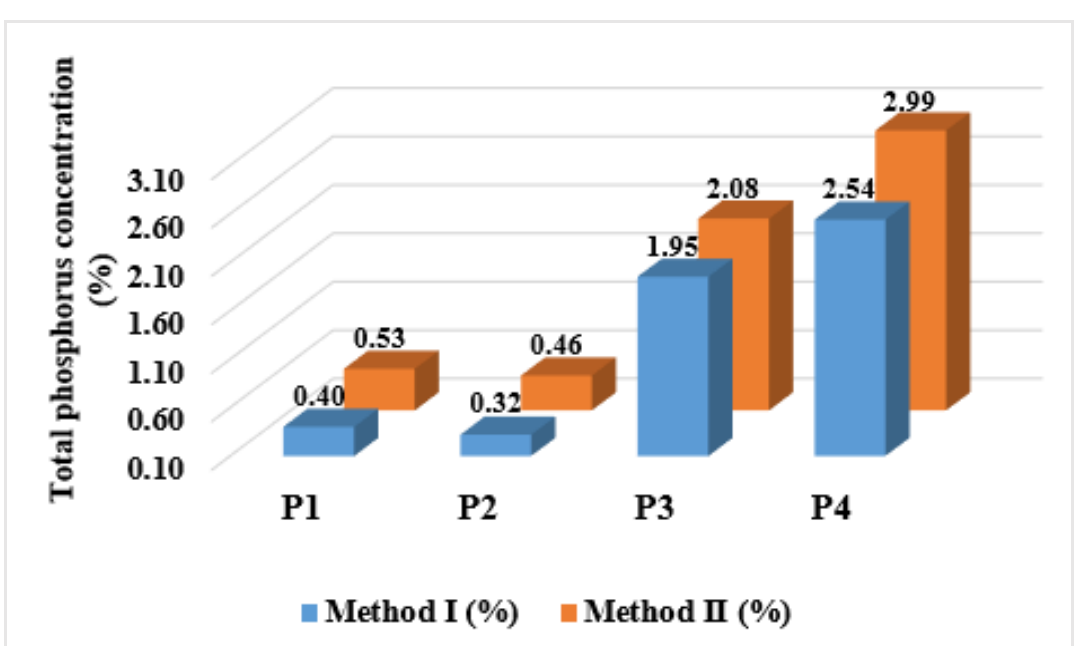

Fig. 3. Graphic representation of total phosphorus concentration obtained with the UV-VIS technique

Results obtained for the reference material

Besides the performance parameters of the ICP- MS method reported in the paper, the 
certificated value for sewage sludge reference results. The results are presented in Table 4. material was compared with the obtained

Table 4. The results obtained for total phosphorous from CRM using digestion methods I and II

\begin{tabular}{cccccc}
\hline Applied & CRM & \multicolumn{4}{c}{ CRM value obtained (\%) } \\
\cline { 3 - 6 } technique & certificate (\%) & Method I & Recovery yield & Method II & Recovery yield \\
\hline ICP-MS & $2.11 \pm 0.260$ & $2.04 \pm 0.286$ & 96.7 & $1.99 \pm 0.279$ & 94.3 \\
UV-VIS & $2.11 \pm 0.260$ & $1.85 \pm 0.333$ & 87.7 & $1.91 \pm 0.344$ & 90.5 \\
\hline
\end{tabular}

The results obtained with the ICP-MS method were much better than the one obtained with the UV-VIS method for both digestion procedures (Table 4).

A long sample preparation time is one important disadvantage of the UV-VIS method (approximately three days). The preparation steps include different operational steps, such as; mineralization, distillation, color development, measurement of the absorbance.

The ICP-MS method is more reliable, because

\section{CONCLUSIONS}

Based on the results obtained it can be concluded that the ICP-MS technique is more reliable for the phosphorus determination from different types of waste in comparison with the UV-VIS technique, due to higher recovery percentage and lower determination time.

Under the conditions described in this study, the costs of analysis for total phosphorus in different types of waste will decrease, leading

\section{ACKNOWLEDGEMENTS}

This work was carried out through the Nucleu Program, financed by the Ministry of Research and Innovation, through contract 20N/2019,

\section{REFERENCES}

[1] ZHENG, Y., FU, W., ZHU, R., HU, Z., CHEN, G., CHAI, X.-S., RSC Adv., 9, 2019, p. 40961.

[2] CHEN, X., WU, H., Fuel, 255, 115755, 2019 , p. 2.

[3] KROISS, H., RECHBERGER, H., EGLE L., Integrated Waste Management - Volume II, Finnish Meteorological Institute, vol. II, 2016, p.181.

[4] MAKKONEN, U., SAARNIO, K., RUOHO-AIROLA, T., HAKOLA, H., 2016, ISBN 978-951-697-874-4.

[5] WORSFOLD, P., MCKELVIE, I., MONBET, P., Anal. Chim. Acta, 918, 2016, p. 9. the obtained results indicate a higher recovery percentage (Table 4). Digestion time is smaller than the one applied in the UV-VIS method, the total phosphorus content could be determined in one day. The results obtained using microwave digestion (method I) indicate a higher recovery percentage for the ICP-MS method.

The results sustained the application of the ICPMS method for the determination of the total phosphorus content from different types of waste.

to the optimization of laboratory management. The internal validation method was developed for all the analyzed matrices and the results reached the desired objective.

The studies have been performed to indicate additional data for the recovery process of P3 (sewage sludge) and P4 (sludge from the meat processing industry) wastes as phosphorusbased fertilizer for soils with P low content.

project code: PN 19040401 and Sectorial Plan financed by Ministry of Agriculture and Rural Development (contract ADER 9.1.2/2019).

[6] ARMBRUSTER, D., ROTT, E., MINKE, R., HAPPEL, O., Anal. Bioanal. Chem. 412, 2020, p. 4809.

[7] SZÖGI, A. A., VANOTTI, M. B., HUNT, P.G., Biores. Technol., 97, no. 1, 2006, p.185.

[8] FALK, J., SKOGLUND, N., GRIMM, A., ÖHMAN, M., Energy Fuels, 34, no. 4, 2020, p. 4587.

[9] DAYTON, E.A., WHITACRE, S., HOLlOMAN, C., Appl. Geochem., 78, 2017, p. 357.

[10] YOKOTA, T., ITO, T., SAIGUSA, M., Sci. Plant Nutr., 49, no. 2, 2003, p.267.

[11] IVANOV K., ZAPRJANOVA P., PETKOV M., STEFANOVA V., KMETOV V., 
GEORGIEVA D., ANGELOVA V., [13] EN 16171:2017, Sludge, treated bio-waste Spectrochim. Acta Part B, 71-72, 2012, p. 117. and soil - Determination of elements using [12] FUENTES, B., BOLAN, N., NAIDU, R., inductively coupled plasma mass spectrometry MORA M., J. Soil Sc. Plant. Nutr., 6, no. 2, (ICP-MS).

2006, p. 64. 